\title{
Effect of Cholecalciferol Supplementation on Glycemic Control, Beta Cell Function and Insulin Resistance among Type 2 Diabetics Attending the Family Medicine Outpatient Clinic Affiliated to Suez Canal University Hospital, Ismailia City, Egypt
}

\author{
DALIA E. IBRAHIM, M.Sc.; HASSAN A. ABD EL-WAHED, M.D.; HANAN A. ABDO, M.D. and \\ ENAYAT M. SOLTAN, M.D.
}

The Department of Family Medicine, Faculty of Medicine, Suez Canal University

\begin{abstract}
Background: Diabetes is a complex chronic illness that adversely affects patients' quality of life. Approximately 425 million adults (20-79 years) were living with diabetes in 2017. Vitamin D levels had been shown to alter insulin synthesis and secretion suggesting its role in the pathogenesis of type 2 diabetes mellitus.
\end{abstract}

Aim of Study: To promote the quality of care provided to type 2 diabetic patients in the family practice setting.

Patients and Methods: This is a randomized controlled trial conducted on 60 uncontrolled type 2 diabetics. Patients were randomly allocated to Vitamin $\mathrm{D}_{3}$ group; received oral daily 2000IU of Cholecalciferol plus their usual care and a control group; received only their usual care for 3 months. Baseline anthropometrics, blood pressure, FBS, $\mathrm{HBA}{ }_{1} \mathrm{C}$, fasting insulin, HOMA indices and lipid profile were measured and repeated after 3 months.

Results: No statistically significant sociodemographic differences were found between both groups. The majority were younger than 60 years, hypertension was found in $76.7 \%$ of them. There were post intervention statistically significant differences $(p<0.05)$ between both groups in blood pressure, FBS and HOMA- $\beta$. The pre-post relation in the intervention group shows statistically significant differences $(p<0.05)$ in blood pressure, FBS, fasting insulin, HOMA- $\beta$ and HOMAIR. There is a statistically significant positive correlation between $\mathrm{HBA}_{1} \mathrm{C}$, blood pressure, and FBS.

Conclusion: Adding a daily dose of 2000IU of oral Vitamin $\mathrm{D}_{3}$ for type 2 diabetic patients may be beneficial through improving blood pressure, fasting blood glucose and HOMA- $\beta$.

Key Words: Diabetes - Cholecalciferol $-\mathrm{HBA}{ }_{1} \mathrm{C}-\mathrm{HOMA}$ $\beta-H O M A-I R$.

Correspondence to: Dr. Dalia E. Ibrahim, The Department of Family Medicine, Faculty of Medicine, Suez Canal University

\section{Introduction}

DIABETES is a complex chronic illness that is aggressively becoming a major burden all over the world [1,2]. Approximately 425 million adults (2079 years) were living with diabetes in 2017 worldwide; by 2045 this will rise to 629 million. IDF (International Diabetes Federation) estimates that about 39 million persons were diagnosed as type 2 diabetics in the Middle East and North Africa in 2017 , a number that will almost double to 82 million by 2045 [3].

Vitamin D levels had been shown to alter insulin synthesis and secretion suggesting its role in the pathogenesis of type 2 diabetes mellitus [4]. The effect of Vitamin D is thought to be through a direct action on beta-cell function, Vitamin D Receptors (VDR) and Vitamin D-binding Proteins (DBP) in the tissue of pancreas [4,5]. Vitamin D at the same time may affect glucose homeostasis by regulation of plasma calcium levels which affects insulin synthesis and secretion [6]

There was a negative correlation between $\mathrm{Vi}$ tamin D serum levels, metabolic control and insulin resistance among diabetic patients [7-9]. Many intervention trials had documented the positive impact of different concentrations of cholecalciferol supplementation on type 2 glycemic control; on the contrary other studies had proved the lack of association between Vitamin D supplementation and improving glycemic control [10].

Type 2 diabetes mellitus is a growing problem in Egypt and it's accompanied by short and long term complications that adversely affect patients' health and quality of life which is associated with 
enormous related costs. So, in this study we are going to improve the quality of care provided to type 2 diabetics in Family Medicine practice through detection whether adding Vitamin D 3 to their routine plan of management will be beneficial or not.

\section{Patients and Methods}

This is a nine months randomized single blinded clinical trial (from September 2016 to May 2017) with a pre-post assessment of the effect of adding oral Cholecalciferol to the treatment regimen for type 2 diabetics attending the Family Medicine clinic, Suez Canal University Hospital, Ismailia City, Egypt. Our inclusion criteria was uncontrolled type 2 diabetics aged 18 years and elder while according to patients' medical records; our exclusion criteria were type 1 diabetes, recent macrovascular complications, decompensated liver disease, chronic kidney disease, known malignancies, Vitamin D supplements within previous 3 months, hypervitaminosis D symptoms, pregnancy and lactation. Ethical clearance from the Institutional Ethical Committee and informed consent from patients were taken. A total of randomly selected 60 type 2 diabetics ( 26 males and 36 females) were included in the study. Our sample size was 60 patients according to this equation:

$$
\mathrm{n}=\frac{[(\mathrm{Z} \alpha / 2+\mathrm{Z}(3) 2 \mathrm{X}\{2(\mathrm{O}) 2\}]}{(\propto 1-\mu 2) 2}[\mathbf{1 1}]
$$

\section{Sampling and random allocation:}

Multistage sampling was used; uncontrolled diabetic patients were selected and then listed by names, 60 uncontrolled diabetic patients had been randomly selected using simple random sampling then they were randomly allocated into a 1:1 allocation ratio. Every patient had an equal chance to be selected either group.

\section{Stages of the study:}

1- Pre-intervention stage: For both groups; an Interview questionnaire [12] was used which covered personal, socio-demographic, medical and drug histories. Body Mass Index (BMI) was calculated by dividing weight $(\mathrm{kg})$ to height $\left(\mathrm{m}^{2}\right)$ [13] Blood Pressure (BP) was recorded after the subjects had rested for at least $5 \mathrm{~min}$. All subjects were asked to submit overnight fasting blood samples to analyze the different metabolic parameters. Sera were separated by centrifuging blood at 3,000rpm for 15 minutes and stored at $-20^{\circ} \mathrm{C}$ until analysis then it was used for estimation of $\mathrm{HBA}{ }_{1} \mathrm{C}, \mathrm{FBS}$, and fasting insulin which was measured using the Cobas ${ }^{\circledR}$ electrochemiluminescence [14] immu- noassay (Elecsys Insulin Assay) with absence of cross-reactivity of exogenous insulin [15]. Sera for lipids were centrifuged for 10 minutes at 3,000rpm, for collection of the aqueous phase. TC, HDL-C, and TG were measured by BioMerieux Laboratory, Marcy l'Etoile, France while LDL-C was calculated according to the Friedewald formula [16].

HOMA indices were calculated through the following equations:

$$
\text { HOMA-IR }=\begin{gathered}
\text { Glucose } \mathrm{X} \text { Insulin } \\
405
\end{gathered}
$$

IR is insulin resistance.

$$
\text { HOMA- } 3=\begin{aligned}
& 360 \times \text { Insulin } \\
& \text { Glucose }-63
\end{aligned}
$$

( 3 is the 3 -cell function.

2- Intervention stage: The intervention group had received Vitamin D 3 supplementation in the form of Cholecalciferol 2000IU daily for 12 weeks. Oral liquid Vitamin D 3 was purchased from the Medical Union pharmaceutical. Each $1 \mathrm{ml}$ of the used drug contains 2800IU of Cholecalciferol (each drop is equivalent to 100IU of Vitamin D 3), so patients were asked to consume a daily dose of 20 drops of the medicine. Patients were instructed to store the medicine in a temperature below $25^{\circ} \mathrm{C}$. The oral route of administration had been selected as it results in less inter-individual variability in achieved serum $25(\mathrm{OH})$ D concentrations compared to the intramuscular route $[\mathbf{1 8 , 1 9 ]}$, it was also used by other investigators in previous studies and showed safety of the dosage regimen that had been used in our trial [20]. The control group didn't receive oral Vitamin D 3 supplementation. Both groups had followed their medications for diabetic control and both were advised on maintaining their usual dietary and physical activity habits at the time of intervention. Instructions to report any kind of therapy other than prescribed were given. Patients were asked to return bottles at every follow-up visit to assess adherence.

Safety: Using 2000IU of Cholecalciferol is a recommended daily dosage by the Institute of Medicine on 2011 [21].

\section{Follow-up and outcome measures:}

On the 12th week of the study; both groups had undergone laboratory investigations for $\mathrm{HBA}_{1} \mathrm{C}$, FBS, fasting insulin and lipid profile. HOMA-IR, HOMA-( 3 were assessed according to the previously discussed equations. All investigations were held at Suez Canal University Hospital Laboratory. Laboratory was blind to groups of therapy. Our 
safety outcomes were according to the reported adverse events; patients developed symptoms similar to that of hypervitaminosis D had been excluded from the study.

\section{Results}

There are statistically significant differences ( $p$-value $<0.05)$ in four outcome variables; systolic blood pressure, diastolic blood pressure, fasting blood sugar and HOMA- $\beta$ after 12 weeks, while the rest of variables didn't show any significance.

The post intervention decrease in systolic, diastolic blood pressure and fasting blood sugar (post-test minus pre-test) is highly statistically significant $(p<0.05)$, on the contrary fasting Insulin, HOMA-IR and HOMA 3 had been increased on the 12 th week of intervention compared to base line values with a statistically significant difference $(p<0.05)$. HOMA-IR is a means to assess the peripheral insulin resistance with a normal value of healthy human ranges from $0.5-1.4$, more than 1.9 indicates early insulin resistance while more than 2.9 indicate significant insulin resistance [22] .

There is a statistically significant difference noted between both groups' post intervention HBAIC ( $p$-value $<0.05)$.

There are statistically significant positive correlations between the post intervention $\mathrm{HBA}_{1} \mathrm{C}$, systolic blood pressure and fasting blood sugar, while both fasting Insulin and HOMA- $\beta$ had statistically significant negative correlations.

There is significant linear association between $\mathrm{HbA}_{1} \mathrm{C}$ with FBS and fasting Insulin.

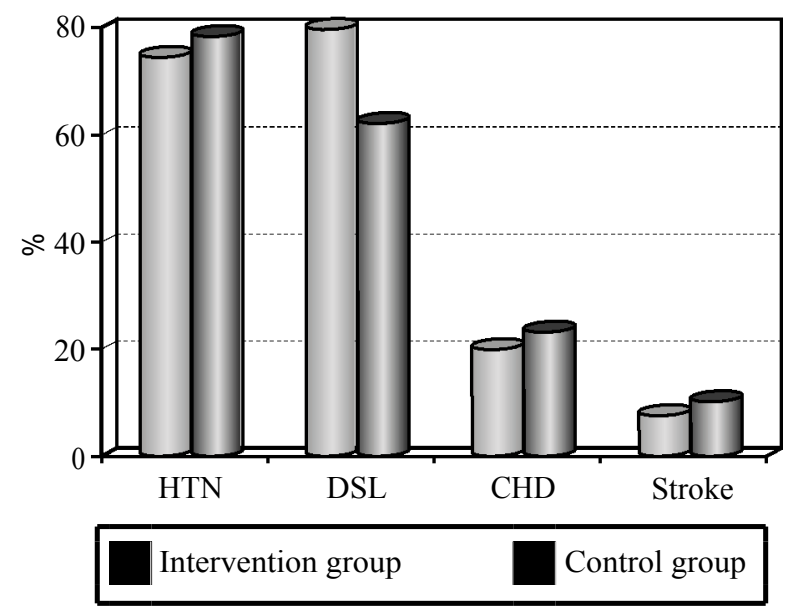

Fig. (1): Distribution of study groups according to their associated comorbidities.
Table (1): Sociodemographic characteristics of the two study groups.

\begin{tabular}{|c|c|c|c|}
\hline Patient variables & $\begin{array}{c}\text { Cholecalciferol } \\
\text { group } \\
(n=30) \%\end{array}$ & $\begin{array}{l}\text { Control } \\
\text { group } \\
(n=30) \%\end{array}$ & $\begin{array}{c}p- \\
\text { value }\end{array}$ \\
\hline \multicolumn{4}{|l|}{ Gender: } \\
\hline - Male & $11(36.7 \%)$ & $13(43.3 \%)$ & \multirow[t]{2}{*}{0.598} \\
\hline - Female & $19(63.3 \%)$ & $17(56.7 \%)$ & \\
\hline \multicolumn{4}{|l|}{ Socio-economic status: } \\
\hline - Very low & $3(10 \%)$ & $4 \quad(13.3 \%)$ & \multirow[t]{3}{*}{0.400} \\
\hline - Low & $14(46.7 \%)$ & $18(60 \%)$ & \\
\hline - Middle & $13(43.3 \%)$ & $8 \quad(26.7 \%)$ & \\
\hline \multicolumn{4}{|l|}{ Usual source of health care: } \\
\hline - More than one source & $7 \quad(23.3 \%)$ & $2(6.7 \%)$ & \multirow[t]{3}{*}{0.129} \\
\hline $\begin{array}{l}\text { - Free governmental health } \\
\text { services }\end{array}$ & $23(76.7 \%)$ & $27(90 \%)$ & \\
\hline - Health insurance & $0 \quad(0 \%)$ & $1 \quad(3.3 \%)$ & \\
\hline \multicolumn{4}{|l|}{ Treatment: } \\
\hline - Oral drugs & $16(53.3 \%)$ & $17(56.7 \%)$ & \multirow[t]{2}{*}{0.795} \\
\hline $\begin{array}{l}\text { - Mixed Insulin either alone or } \\
\text { combined with Metformin }\end{array}$ & r $14(46.7 \%)$ & $13(43.3 \%)$ & \\
\hline
\end{tabular}

Table (2): Baseline clinical characteristics of the study groups.

\begin{tabular}{lllllll}
\hline \multirow{2}{*}{$\begin{array}{l}\text { Clinical } \\
\text { characteristics }\end{array}$} & \multicolumn{2}{c}{$\begin{array}{c}\text { Cholecalciferol } \\
\text { group }(\mathrm{n}=30)\end{array}$} & \multicolumn{2}{c}{$\begin{array}{c}\text { Control group } \\
(\mathrm{n}=30)\end{array}$} & $\begin{array}{c}t- \\
\text { value }\end{array}$ & $\begin{array}{c}p \text { - } \\
\text { value }\end{array}$ \\
\cline { 2 - 5 } & Mean & S.D & Mean & S.D & & \\
\hline Age & 54.57 & 6.01 & 54.40 & 6.08 & 0.11 & 0.915 \\
Weight & 85.1 & 11.09 & 85.20 & 12.03 & 0.03 & 0.973 \\
BMI & 31.47 & 3.42 & 30.54 & 4.17 & 0.94 & 0.353 \\
Systolic BP & 130.50 & 12.41 & 131.00 & 15.89 & 0.136 & 0.892 \\
Diastolic Bp & 82.00 & 6.51 & 82.17 & 7.6 & 0.091 & 0.928 \\
\hline
\end{tabular}

S.D : Standard Deviation.

BMI : Body Mass Index.

SES : Socioeconomic Status.

B.P : Blood Pressure.

Table (3): Comparison between study groups regarding clinical and biochemical outcome variables in the ${ }^{\text {th }}$ week of follow-up.

\begin{tabular}{lllllll}
\hline $\begin{array}{l}\text { Out-come } \\
\text { variables } \\
(12 \text { th week) }\end{array}$ & $\begin{array}{l}\text { Intervention } \\
\text { group }(\mathrm{n}=29)\end{array}$ & $\begin{array}{l}\text { Control group } \\
(\mathrm{n}=30)\end{array}$ & $\begin{array}{c}t- \\
\text { value }\end{array}$ & $\begin{array}{c}p \text { - } \\
\text { value }\end{array}$ \\
\cline { 2 - 5 } & Mean (SD) & Mean & (SD) & & \\
\hline Systolic BP & 118.97 & 13.91 & 131.67 & 17.68 & 3.059 & $0.003^{*}$ \\
Diastolic BP & 73.28 & 5.39 & 81.17 & 7.85 & 4.49 & $0.000^{*}$ \\
Weight & 85.34 & 10.27 & 86.27 & 10.92 & 0.334 & 0.740 \\
BMI & 31.53 & 3.1 & 30.54 & 3.73 & 1.108 & 0.273 \\
FBS & 156.48 & 45.39 & 193.27 & 37.48 & 3.401 & $0.001^{*}$ \\
HbA1 C & 8.07 & 1.17 & 8.59 & 1.23 & 1.67 & 0.1 \\
Fasting Insulin & 23.29 & 13.58 & 17.31 & 9.45 & 1.97 & .05 \\
HOMA-IR & 8.31 & 4.09 & 7.91 & 4.14 & 0.371 & 0.712 \\
HOMA- $\beta$ & 153.9 & 248.3 & 55.73 & 43.7 & 2.13 & $0.037^{*}$ \\
LDL & 113.8 & 39.43 & 116.47 & 24.94 & 0.308 & 0.759 \\
HDL & 43.31 & 10.77 & 40.4 & 10.77 & 1.04 & 0.304 \\
TG & 148.8 & 78.46 & 155.37 & 74.13 & 0.322 & 0.748 \\
\hline
\end{tabular}

**: $n=59$ because of one patient withdrawal in the intervention group. HOMA-IR: Hemostatic Model Assessment for Insulin Resistance. HOMA- $\beta$ : Hemostatic Model Assessment for Insulin Beta cell function.

* $\quad$ Statistically significant $(p$-value $<0.05)$

S.D : Standard Deviation.

B.P : Blood Pressure.

F.B.S : Fasting Blood Sugar.

HbA1 C : Glycosylated Hemoglobin.

LDL : Low Density Lipoprotein.

HDL : High Density Lipoprotein.

TG : Triglycerides. 
Table (4): Comparison between pre intervention (baseline) and post intervention (12 ${ }^{\text {th }}$ week) followup regarding the outcome variables of the intervention group (Cholecalciferol group; $\mathrm{n}=29 * *)$.

\begin{tabular}{|c|c|c|c|c|c|c|c|c|}
\hline \multirow{2}{*}{$\begin{array}{l}\text { Outcome } \\
\text { variables }\end{array}$} & \multicolumn{2}{|c|}{$\begin{array}{c}\text { Pre } \\
\text { intervention }(t 0)\end{array}$} & \multicolumn{2}{|c|}{$\begin{array}{c}\text { Post } \\
\text { intervention }(t 2)\end{array}$} & \multicolumn{2}{|c|}{$\begin{array}{l}\text { Mean difference } \\
\quad t 0-t 2\end{array}$} & \multirow{2}{*}{$\begin{array}{c}t- \\
\text { value }\end{array}$} & \multirow{2}{*}{$\begin{array}{c}p- \\
\text { value }\end{array}$} \\
\hline & Mean & S.D & Mean & S.D & Mean & S.D & & \\
\hline Systolic BP & 130.52 & 12.63 & 118.97 & 13.91 & 11.55 & 13.24 & 0.000 & $0.000^{*}$ \\
\hline Diastolic BP & 81.9 & 6.6 & 73.28 & 5.8 & 8.62 & 8.65 & 0.137 & $0.000^{*}$ \\
\hline Weight & 85.34 & 11.21 & 85.34 & 10.27 & 0.000 & 2.44 & 4.70 & 1 \\
\hline BMI & 31.56 & 3.44 & 31.53 & 3.1 & 0.03 & 1.22 & 5.37 & 0.892 \\
\hline FBS & 174.52 & 43.57 & 156.48 & 45.39 & 18.04 & 38.11 & 2.55 & $0.017^{*}$ \\
\hline HBA1C & 8.41 & 1.01 & 8.07 & 1.17 & 0.34 & 1.042 & 1.77 & 0.89 \\
\hline F. Insulin & 17.26 & 13.06 & 23.29 & 13.58 & -6.024 & 11.57 & 2.8 & $0.009 *$ \\
\hline HOMA-IR & 7 & 4.67 & 8.3 & 4.01 & -1.34 & 3.45 & 2.09 & $0.05^{*}$ \\
\hline HOMA-P & 73.82 & 75.47 & 153.94 & 248.38 & -80.12 & 205.43 & 2.1 & $0.045^{*}$ \\
\hline LDL & 123.1 & 38.73 & 113.8 & 39.43 & 9.28 & 27.25 & 1.8 & 0.077 \\
\hline HDL & 42.6 & 9.14 & 43.3 & 10.78 & -0.66 & 8.84 & 0.4 & 0.693 \\
\hline TG & 149 & 69.13 & 149 & 78.46 & 0 & 58.51 & 0 & 1 \\
\hline
\end{tabular}

** $\quad: n=29$ because of one patient withdrawal in the intervention group

HOMA-IR : Hemostatic Model Assessment for Insulin Resistance.

HOMA-P : Hemostatic Model Assessment for Insulin Beta cell function.

$\begin{array}{llll}t 0 & : \text { Pre-test. } & t 0 & \text { : Pre-test. } \\ t 2 & : \text { Post-test. } & t 2 & : \text { Post-test. } \\ \text { S.D } & : \text { Standard Deviation. } & \text { S.D }: \text { Standard Deviation. } \\ \text { B.P } & : \text { Blood Pressure. } & \text { B.P }: \text { Blood Pressure. }\end{array}$

F.B.S : Fasting Blood Sugar. F.B.S : Fasting Blood Sugar.

Table (5): Relation between patients' adherence to their medications and the $12^{\text {th }}$ week FBS and $\mathrm{HBA}_{1} \mathrm{C}$

\begin{tabular}{|c|c|c|c|c|c|c|}
\hline \multirow{2}{*}{$\begin{array}{l}\text { Outcome } \\
\text { variables }\end{array}$} & \multicolumn{2}{|c|}{$\begin{array}{l}\text { Adherent } \\
(n=27)\end{array}$} & \multicolumn{2}{|c|}{$\begin{array}{c}\text { Non-adherent } \\
(\mathrm{n}=2)\end{array}$} & \multirow{2}{*}{$\begin{array}{c}t- \\
\text { value }\end{array}$} & \multirow{2}{*}{$\begin{array}{c}p- \\
\text { value }\end{array}$} \\
\hline & Mean & S.D & Mean & S.D & & \\
\hline 12th week FBS & 154.3 & 46.1 & 185.5 & 24.7 & 0.935 & 0.358 \\
\hline 12th week HBA1C & 7.95 & 1.12 & 9.7 & 0.42 & 2.17 & $0.039 *$ \\
\hline
\end{tabular}

**: $n=29$ because of one patient withdrawal.

Table (6): Correlation between $\mathrm{HBA}_{1} \mathrm{C}$ and patient's continuous variables on $(\mathrm{n}=59 * *)$.

\begin{tabular}{lll}
\hline Variables & \multicolumn{1}{c}{$r$} & $p$ \\
\hline Age & 0.106 & 0.426 \\
BMI & -0.116 & 0.382 \\
Systolic blood BP & 0.445 & $0.000^{*}$ \\
Diastolic BP & 0.237 & 0.071 \\
FBS & 0.829 & $0.000^{*}$ \\
Fasting insulin & -0.509 & $0.000^{*}$ \\
HOMA-IR & -0.202 & 0.124 \\
HOMA-P & -0.445 & $0.000^{*}$ \\
LDL & 0.247 & 0.06 \\
HDL & -0.067 & 0.612 \\
Triglycerides & 0.212 & 0.108 \\
\hline
\end{tabular}

Dependent variable: Post intervention $\mathrm{HbA1} \mathrm{C}$.

$r \quad:$ : Pearson's correlation coefficient.

** $\quad: n=59$ because of one patient withdrawal in the intervention group.

F.B.S : Fasting Blood Sugar

HbA1C : Glycosylated Hemoglobin.

HOMA-IR : Hemostatic Model Assessment for Insulin Resistance.

HOMA-P : Hemostatic Model Assessment for Insulin Beta Cell

Function.

Statistically significant ( $p$-value $<0.05$ ).
Table (7): Multiple regression (analysis of variance, ANOVA): Predictors of post intervention $\mathrm{HBA}_{1} \mathrm{C}$ in the $12^{\text {th }}$ week of follow-up in both study group.

\begin{tabular}{llccccc}
\hline & \multicolumn{2}{c}{$\begin{array}{c}\text { Un-standardized } \\
\text { coefficients }\end{array}$} & & & \\
& B & Std. Error & & Beta & & $p$ \\
\cline { 2 - 3 } & 4.202 & 0.789 & & 5.33 & 0.000 \\
(Constant) & 0.021 & 0.002 & & 0.767 & 8.36 & $0.000^{*}$ \\
FBS & 0.007 & 0.006 & & 0.094 & 1.177 & 0.244 \\
Systolic BP & -0.023 & 0.011 & & -0.221 & -2.06 & $0.044^{*}$ \\
Fasting Insulin & -0.001 & 0.001 & & 0.156 & 1.409 & 0.165 \\
HOMA-P & 0.001 & & &
\end{tabular}

Dependent Variable: HbA1C on the 12th week of follow-up. F.B.S

BP

$\mathrm{HbA} 1 \mathrm{C}$

HOMA-P

function

: Statistically significant ( $p$-value $<0.05)$

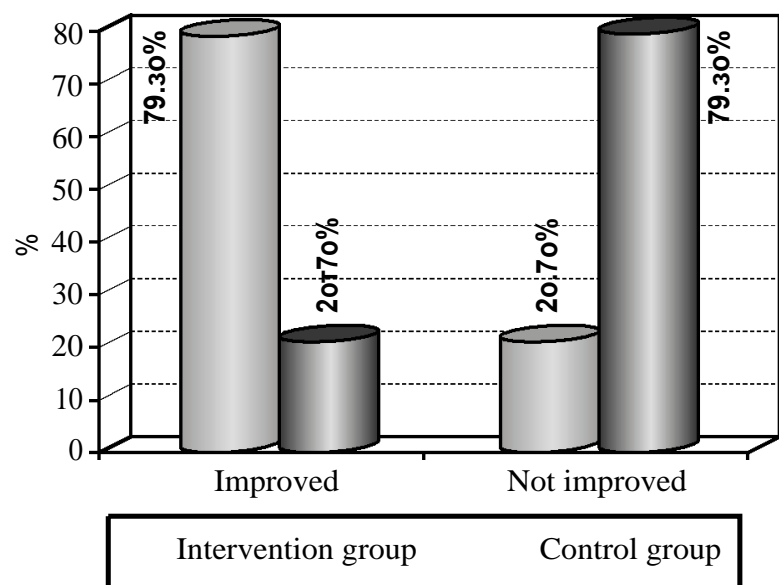

Fig. (2): Distribution of the study groups regarding their glycemic improvement on $12^{\text {th }}$ week follow-up $(n=59)$. 


\section{Discussion}

\section{Socio-demographic characteristics:}

The majority of our patients in both groups were younger than 60 years. This finding is in congruence with Al-Daghri et al., [23], Al-Sofiani et al., [24] and Al-Shahwan et al., [10] . It was confirmed that age is one of the important risk factors for $\mathrm{T}_{2} \mathrm{DM}$ as aging induces decreased insulin sensitivity and insufficient compensation of beta cell function in the face of increased insulin resistance [25]. In our study; female gender was slightly higher among patients of both groups in a percentage of 60 similarly; Heshmat et al., had $64 \%$ female subjects [26]. Female gender was high in our study population as it reflects the frequency of gender distribution among the attendants of the Family Medicine Clinic. More than half of our study population was of the low socioeconomic level in a percentage of 53.3 which was harmonious with other studies like Veghari et al., [27] and Hwang et al., [28] that were all carried out in developing low income countries under similar circumstances. Simultaneously our study setting is considered a governmental institution whose customers are mainly of the low socioeconomic level searching for getting the benefit of the free governmental services that had been used by more than three fourths $(83.3 \%)$ of the studied population. This is in agreement with the DeVoe et al., [29] who found that more than $87 \%$ of the diabetic individuals in the U.S. had full-year coverage with Usual Source of Care, whereas Zhang et al., [30] had estimated $16.0 \%$ of known diabetic adults were uninsured.

Associated comorbidities and antihyperglycemic medications:

Hypertension and dyslipidemia were the most prevalent chronic illnesses among the study population $(76.7 \%$ and $68.3 \%$ respectively). Jelinek et al., [17] had the same declaration as he had found that hypertension $(83.40 \%)$ and dyslipidemia $(93.43 \%)$ were the most common associated comorbidities to type 2 diabetes that is in congruence to the findings of the Indian study by Borah et al., [31]. Whiledisagreed with Reddy et al., [32] who found only $33.3 \%$ of their diabetic participants had hypertension.

In this study more than half of our patients used Oral Glucose Lowering Drugs (OGLD) for the control of their $\mathrm{T}_{2} \mathrm{DM}(53.3 \%$ and $56.7 \%$ in intervention and control groups respectively) without significant difference between both groups. This is in agreement with the results of Chadli et al., [33] who estimated $61 \%$ were treated with an OGLD alone while $23 \%$ received an OGLD plus insulin and $13 \%$ received insulin only. On the other hand Hanne et al., [34] found OGLD were used as monotherapy in only $39.4 \%$ while insulin was used in $54.5 \%$.

\section{Baseline clinical and biochemical characteristics:}

Our distributions of the baseline clinical and biochemical characteristics were identical across the treatment groups and this is in congruence to the findings by Forouhi et al., [35]. Most of our patients in both groups were obese in agreement with Al-Shahwan et al., and Nada et al., [10,36] However the majority of the current participants had controlled blood pressure which is consistent with Forouhi et al., and Nada et al., [35,36]

The baseline $\mathrm{HBA}_{1} \mathrm{C}$ among our participants showed a non significantly slightly higher value in the Cholecalciferol group than that of the control group which is consistent with Hanne et al., [34] and was higher than what was reported in SUNNY trial by Yvonne et al., [38]. Most of patients in both groups were dyslipidemic; the mean LDL was $123.1 \mathrm{mg} / \mathrm{dl}$ and $115 \mathrm{mg} / \mathrm{dl}$ in the intervention and control groups respectively which was conflicting with the results of Yvonne et al., [37], Al-Daghri et al., [23] and Nada et al., [36] whose participants had within normal serum lipids, this difference may be related to recruitment methods and sample size variation. Nevertheless, the present study unexpectedly corresponded with the previously mentioned studies $[23,36]$ in the basal levels of fasting insulin, HOMA-IR and HOMA- $\beta$ cell function.

\section{The post intervention effects:}

There were decreases in systolic, diastolic blood pressure and fasting blood sugar which were highly statistically significant, on the contrary fasting Insulin, HOMA-IR and HOMA $\beta$ had been increased on the 12 th week of the intervention compared to baseline values with statistically significant differences too. This is in agreement with recent systematic reviews that had suggested beneficial effects of Vitamin D supplementation in poorly controlled diabetics [38,39]. Antihypertensive activity of Vitamin D could be related to negative regulatory effect of Vitamin $\mathrm{D}$ on renin production [40]. Despite the lack of significance of HBAIC reduction between current both groups that agreed with Calvo et al., and other studies [34,37,41]; our study reported statistically significant differences between intervention and controls regarding fasting blood glucose (156.48 \pm 45.39 versus $193.27 \pm 37.48$ respectively) that agreed with Hanne et al., and Yvonne et al., [34,37] 
In a non corresponding comparison between pre and post biochemical parameters of their participants; Nada et al., [36] found a significant reduction of $\mathrm{HbA}_{1} \mathrm{c}(7.9 \pm 1.7$ versus $7.4 \pm 1.2)$ and FPG (9.1 \pm 4.3 versus $7.9 \pm 2.4, p=0.034)$, this agreed with the study of Soric et al., [42] in which patients had a significantly greater reduction in $\mathrm{HbA}_{1} \mathrm{c}$ on receiving Vitamin D for 12 weeks. This reduction was only significant when baseline $\mathrm{HbA}_{1} \mathrm{c}$ was $>9 \%$.

The significant differences in (3 -cell activity within the intervention group and between both our study groups were associated with a nonstatistically significant superiority in fasting serum insulin levels in the intervention group which disagreed with Calvo et al., [41] that had found a non significant reduction in fasting insulin and disagreed with Borissova et al., and Inomata et al., $[\mathbf{4 3}, \mathbf{4 4}]$ which concluded that three to four weeks of Vitamin D supplementations were sufficient to improve insulin secretion. Similar improvements in HOMA-( 3 and insulin secretion were noted in Arab participants after daily supplementations with the same dose of 2000IU of Cholecalciferol [10] despite lack of statistically significant difference in $\mathrm{HbA}_{1} \mathrm{c}$ between groups after 18 months of Vitamin D intake.

Coinciding our realization of the improvement of HOMA-(3 and fasting insulin; Vaidya et al., [45] had found that HOMA- ( 3 had increased significantly by $35.9 \%$ and insulin had increased by $1.82 \propto \mathrm{U} / \mathrm{mL}$ compared with baseline. However $\mathrm{HbA}_{1} \mathrm{c}$ levels didn't show such improvement [45].

Contradiction with our non statistically but clinically significant improvement in the serum lipids (LDL, HDL and TG) in the intervention group, Al-Daghri et al., [23] had reported a significant improvement in the lipid profile as evidenced by the decrease in LDL-cholesterol which was in agreement with Jafari et al., [46] that had found significantly improved only serum TC and LDL$\mathrm{C}$ in patients with T2DM through Vitamin D intervention. Baseline Vitamin D3, its dosage, intervention duration, and the method of its intake influence the effect on lipid markers.

Several possible explanations exist for the lack of beneficial effect of Vitamin D on some metabolic outcomes related to glucose; the appropriate dose for non-skeletal benefits of Vitamin D still remains unclear, baseline Vitamin D status is a potential confounder on glycemic status, genetic factors related to Vitamin D metabolism might play a role and individual variability may also be partly ex- plained by Vitamin D receptor polymorphisms. Moreover, the lack of significant association might have occurred due to our power calculations that may have been too optimistic, and it is possible that a larger sample size and longer follow-up would be needed to observe an effect. Diabetes related reasons likely responsible for not finding a beneficial effect with Vitamin D treatment include degree of hyperglycemia and duration of diabetes which were two limitations in our study.

Relation between different outcomes and patient variables:

We found a statistically significant difference noted between the adherent and non adherent groups in 12 th week HBA ${ }_{1}$ C. Correspondingly; Gordon et al., [47] concluded that increasing levels of medication adherence were typically associated with greater 1-year $\mathrm{HbA} 1 \mathrm{c}$ reductions across all lines of oral antihyperglycemic therapy that was consistent with McClintock et al., [48].

In the current study there was statistically significant positive correlation between the post intervention $\mathrm{HBA}_{1} \mathrm{C}$ and fasting blood sugar which is in agreement with Zhou J et al., [49] and Behary et al., [50], while both fasting Insulin and HOMA(3 had statistically significant negative correlation with our participants' 12 th week $\mathrm{HBA}_{1} \mathrm{C}$; corresponding to the findings of Al-Hakeim et al., and Bower et al., [51,52] and opposing Dahlqvist et al., [53] who reported Positive correlation between $\mathrm{HBA}_{1} \mathrm{C}$ and fasting insulin. Unlike our negative results; other studies proved significant correlations between $\mathrm{HBA}_{1} \mathrm{C}$ and other patients' variables; Hammad et al., [54] had documented that patients income was negatively correlated with $\mathrm{HBA}_{1} \mathrm{C}$, while Borah et al., [31] found that BMI showed positive correlation with $\mathrm{HbA}_{1} \mathrm{C}$. There was positive correlation between $\mathrm{HbA}_{1} \mathrm{c}$ and serum lipids (TG, LDL) among the Afghani diabetics through Husain et al study [55].

The current results showed significant linear association between $\mathrm{HbA}_{1} \mathrm{C}$ with FBS and fasting Insulin that agreed with Zhou et al., [49], whereas age, duration of illness and income significantly predicted A $1 \mathrm{C}$ by Hammad and his colleagues [54]. Al-Hakeim et al., [51] had confirmed significant linear association between $\mathrm{HBA}{ }_{1} \mathrm{C}$ with HOMA-(3

Our study had detected a highly statistically significant difference between both groups in the post intervention glycemic improvement through $\mathrm{HBA}_{1} \mathrm{C}$ reduction $(79.3 \%$ versus $20.7 \%$ in the intervention and control groups respectively) which 
was compatible with Anyanwu et al., [56] who found the proportion of participants with poor glycemic control $\left(\mathrm{HBA}_{1} \mathrm{c}>6.5 \%\right)$ who converted to good control after Vitamin D supplementation was significantly higher in the treatment arm compared to control (33.3\% in the intervention group versus $-9.1 \%$ in the control). Our findings are in agreement with the results of many studies [42,5759]. The strengths of the present study were its prospective, randomized design, stable treatment regimen throughout the study, objective assessment of endpoints and compliance to medication.

\section{Conclusion:}

Type 2 diabetic patients may benefit from adding a daily dose of 2000IU of oral Vitamin D 3 supplementation to their management plan through improving some cardiovascular parameters like systolic and diastolic blood pressure, fasting blood glucose and HOMA- $\beta$.

\section{Recommendations:}

Further studies for better understanding of diabetic patients' needs, knowledge and expectations about Vitamin D deficiency and its supplementation to improve their quality of life as well as a survey team to assess prevalence of Vitamin $\mathrm{D}$ deficiency among them are needed.

\section{References}

1- American Diabetes Association: Standards of Medical Care in Diabetes. Diabetes Care, 40: 1-99, 2017.

2- Academic Medical Centre; University of Amsterdam: Prevalence and complications of diabetes mellitus in Northern Africa: A systematic review. B.M.C. Public Health, 13: 387, 2015.

3- International Diabetes Federation: Global estimates of the prevalence of diabetes for 2017: IDF Diabetes Atlas. Available at https://www.idf.org/aboutdiabetes/what-isdiabetes/facts-figures.

4- AKIN F., AYÇA B., KÖSE N., DURAN M., SAR M., UYSAL O.K., et al.: Serum Vitamin D levels are independently associated with severity of coronary artery disease. Cardiovasc. Diabetol., 11: 8, 2012.

5- PALOMER X.1., GONZÁLEZ-CLEMENTE J.M., BLANCO-VACA F. and MAURICIO D.: Role of Vitamin D in the pathogenesis of type 2 diabetes mellitus. Diabetes Obes. Metab., 10: 185-97, 2008.

6- ELKASSABYS1, HARRISONLC2, MAZZITELLIN1, WENTWORTHJM3, COLMAN PG4, SPELMAN T, et al.: A randomised controlled trial of high dose Vitamin $\mathrm{D}$ in recent-onset type 2 diabetes. Diabetes Res. Clin. Pract., 106: 576-82, 2014.

7- ROSS A.: The 2011 report on dietary reference intakes for calcium and Vitamin D. Public Health Nutr., 14: 9389, 2011.
8- CALVO-ROMERO J.M. 1. and RAMIRO-LOZANO J.M.: Vitamin D Levels in Patients with Type 2 Diabetes Mellitus. Med., 63: 92-923, 2015.

9- ALHUMAIDI M., AGHA A. and DEWISH M.: Vitamin D Deficiency in Patients with Type-2 Diabetes Mellitus in Southern Region of Saudi Arabia. Maedica Journal of Clinical Medicine, 8: 231-6, 2013.

10-AL-SHAHWAN M.A., AL-OTHMAN A.M., AL-DAGHRI N.M. and SABICO S.B.: Effects of 12-month, 2000IU/day Vitamin D supplementation on treatment naïve and Vitamin D deficient Saudi type 2 diabetic patients. Saudi Medical Journal, 36: 12, 2015.

11- Sakpal T.V.: Sample Size Estimation in Clinical Trial. Perspectives in Clinical Research, 1: 67, 2010.

12- EL-GILANY A., EL-WEHADY A. and EL-WASIFY M.: Updating and validation of the socioeconomic status scale for health research in Egypt. Eastern Mediterranean Health Journal, 18: 9, 2012.

13- Centers of Disease Control and Prevention: Body Mass Index. Considerations for Practitioners. [up dated 2014; Availablefrom: http://www.cdc.gov/obesity/downloads/ bmiforpactitioners.pdf.

14- Elecsys Insulin English System Information for Cobas E 411 Analyzer: Test Number 650 for Modular Analytics E170, cobas e 601 and cobas e 602 analyzers: Application Code Number 120. Available at http: //labogids.sintmaria. be/sites/default/files/files/insulin 2017-06 v15.pdf.

15- SAPIN R., Le GALDEC V., GASSER F., PINGET M. and GRUCKER D.: Elecsys Insulin Assay: Free Insulin Determination and the Absence of Cross-Reactivity with Insulin Lispro. Clinical Chemistry, 47: 602-5, 2001.

16- KNOPFHOLZ J., DINIZ DISSEROL C., PIERIN A., SCHIRR F., STREISKY L., TAKITO L., et al.: Validation of the Friedewald Formula in Patients with Metabolic Syndrome. Cholestrol, 2014: 1-5, 2014.

17- MATTHEWS D., HOSKER J., RUDENSKI A., NAYLOR B., TREACHER D. and TURNER R.: Homeostasis model assessment: Insulin resistance and beta-cell function from fasting plasma glucose and insulin concentrations in man. Diabetologia, 28: 412-9, 1985.

18- VIETH R.: Vitamin D supplementation, 25-hydroxyvitamin D concentrations, and safety. Am. J. Clin. Nutr., 69: 84256, 1999.

19- HEANEY R.P., DAVIES K.M., CHEN T.C., HOLICK M.F. and BARGER M.J.: Human serum 25-hydroxycholecalciferol response to extended oral dosing with cholecalciferol. Am. J. Clin. Nutr., 77: 204-10, 2003.

20- BARGER M.J., HEANEY R.P., DOWELL S., CHEN T.C. and HOLICK M.F.: Vitamin D and its major metabolites: Serum levels after graded oral dosing in healthy men. Osteoporosis In, 8: 222-30, 1998.

21- ROSS A., JOANN E., STEVEN A., JOHN F., PATSY M., STEVEN K., et al.: The 2011 Report on Dietary Reference Intakes for Calcium and Vitamin D from the Institute of Medicine: What Clinicians Need to Know. J. Clin. Endocrinol. Metab., 96 (1): 53-8, 2011.

22- FORBATH N. and HETENYI G.: Glucose dynamics in normal subjects and diabetic patients before and after a glucose load. Diabetes, 15: 778-89, 1999. 
23- AL-DAGHRI N., ALKHARFY K., AL-OTHMAN A., EL-KHOLIE E., MOHARRAM O., ALOKAIL M., et al.: Vitamin D supplementation as an adjuvant therapy for patients with T2DM: An 18-month prospective interventional study. Cardiovascular. Diabetol., 18 (11): 85, 2012.

24- AL-SOFIANI M., JAMMAH A., RACZ M., KHAWAJA R., HASANATO R., EL-FAWAL H., et al.: Effect of Vitamin D Supplementation on Glucose Control and Inflammatory Response in Type II Diabetes: A Double Blind, Randomized Clinical Trial. Int. J. Endocrinol. Metab., 13 (1), 2015.

25- CHANG A.M. and HALTER J.B.: Aging and insulin secretion. Am. J. Physiol. Endocrinol. Metab., 284: E712, 2003.

26- HESHMAT R., TABATABAEI-MALAZY O., ABBASZADEH-AHRANJANI S., SHAHBAZI S., KHOOSHEHCHIN G. and BANDARIAN F.: Effect of Vitamin D on insulin resistance and anthropometric parameters in Type 2 diabetes; a randomized double-blind clinical trial. Daru., 20 (1): 10, 2012.

27- VEGHARI G., SEDAGHAT M., JOSHAGHANI H., HOSEINI A., NIKNEZAD F. and ANGIZEH A.: Association between socio-demographic factors and diabetes mellitus in the north of Iran: A population-based study. International Journal of diabetes, 2: 154-7, 2010.

28- HWANG J. and SHON C.: Relationship between socioeconomic status and type 2 diabetes: Results from Korea National Health and Nutrition Examination Survey (KNHANES) 2010-2012. B.M.J. Open, 4 (8): e005710, 2014.

29- DEVOE J., TILLOTSON C. and WALLACE L.: Usual Source of Care as a Health Insurance Substitute for U.S. Adults with Diabetes? Diabetes Care, 32 (6): 983-9, 2009.

30- ZHANG X., BULLARD K., GREGG E., BECKLES G., WILLIAMS D., BARKER L., et al.: Access to Health Care and Control of ABCs of Diabetes. Diabetes care, 35 (7): 1566-71, 2012

31- BORAH M. and GOSWAMI R.: Sociodemographic and clinical characteristics of a diabetic population at a tertiary care center in Assam, India. Journal of Social Health and Diabetes, 5: 37-42, 2017.

32- REDDY S.S. and PRABHU G.R.: Prevalence and risk factors of hypertension in urban slums, Tirupati. Indian J. Community Med., 3: 85-6, 2005.

33- CHADLI A., EL AZIZ S., EL ANSARI N., AJDI F., SEQAT M., LATRECH H., et al.: Management of diabetes in Morocco: Results of the International Diabetes Management Practices Study (IDMPS)-wave 5. Ther. Adv. Endocrinol. Metab., 7 (3): 101-9, 2016.

34- HANNE L., WIUM C., ANGEL K., ERIKSEN and BIRKELAND K.: Effects of Vitamin D supplementation on insulin sensitivity and insulin secretion in subjects with type 2 diabetes and Vitamin D deficiency: A randomized controlled trial. Diabetes care, 40 (7): 872-8, 2017.

35- FOROUHI N., MENON R., SHARP S., MANNAN N., TIMMS P. and MARTINEAU A.: The effects of vitamin D2 or D3 supplementation on glycemic control and cardiometabolic risk among people at risk of type 2 diabetes: Results of a randomised double-blind placebo-controlled trial. Diabetes Obes. Metab., 6: 1-31, 2016.
36- NADA M. and SHAHEEN D.: Cholecalciferol improves glycemic control in type 2 diabetic patients: A 6-month prospective interventional study. Therapeutics and Clinical Risk Management, 13: 813-20, 2017.

37- YVONNE H., POEL K., WESTRA S., BOEKEL E., NATASJA M., SCHOOR V., et al.: Effect of Vitamin D Supplementation on Glycemic Control in Patients With Type 2 Diabetes: SUNNY Trial: A Randomized PlaceboControlled Trial. Diabetes care, 38: 1420-6, 2015.

38- KRUL-POEL Y.H., TER WEE M.M., LIPS P. and SIMSEK S.: Management of endocrine disease: The effect of Vitamin D supplementation on glycaemic control in patients with type 2 diabetes mellitus: A systematic review and meta-analysis. Eur. J. Endocrinol, 176: R1-R14, 2017.

39- GEORGE P., PEARSON E. and WITHAM M.: Effect of Vitamin D supplementation on glycaemic control and insulin resistance: A systematic review and meta-analysis. Diabetic Medicine, e: 142-50, 2012.

40- SIGMUND C.: Regulation of renin expression and blood pressure by Vitamin D3. J. Clin. Invest., 110 (2): 155-6, 2002.

41- CALVO-ROMERO J.M.1. and RAMIRO-LOZANO J.M.2.: Metabolic effects of supplementation with Vitamin D in type 2 diabetic patients with Vitamin D deficiency. Diabetes Metab. Syndr., 871: 30034-5, 2015.

42- SORIC M.M., RENNER E.T. and SMITH S.R.: Effect of daily Vitamin D supplementation on $\mathrm{HbA}_{1} \mathrm{c}$ in patients with uncontrolled type 2 diabetes mellitus: A pilot study. J. Diabetes, 4 (1): 104-5, 2012.

43- BORISSOVA A.M., TANKOVA T., KIRILOV G., DAKOVSKA L. and KOVACHEVA R.: The effect of Vitamin D3 on insulin secretion and peripheral insulin sensitivity in type 2 diabetic patients. Int. J. Clin. Pract., 57 (4): 25861, 2003.

44- INOMATA S., KADOWAKI S., YAMATANI T., FUKASE M. and FUJITA T.: Effect of 1 alpha $(\mathrm{OH})$-Vitamin D3 on insulin secretion in diabetes mellitus. Bone Miner, 1 (3): 187-92, 1986.

45- VAIDYA A. and WILLIAMS J.S.: The relationship between Vitamin D and the renin-angiotensin system in the pathophysiology of hypertension, kidney disease, and diabetes. Metabolism, 61 (4): 450-8, 2012.

46- JAFARI T., FALLAH A.A. and BARANI A.: Effects of Vitamin D on serum lipid profile in patients with type 2 diabetes: A meta-analysis of randomized controlled trials. Clin. Nutr., 35 (6): 1259-68, 2016.

47- GORDON J., MCEWAN P.H., IDRIS I., EVANS M. and PUELLE J.: Treatment choice, medication adherence and glycemic efficacy in people with type 2 diabetes: A UK clinical practice database study. B.M.J. open diabetes research \& care, 6: e000512, 2018.

48- MCCLINTOCK H., MORALES K., SMALL D. and BOGNER H.: A Brief Adherence Intervention that Improved Glycemic Control: Mediation by Patterns of Adherence. J. Behav. Med., 38 (1): 39-47, 2015.

49- ZHOU J., MO Y., LI H., RAN X., YANG W., LI Q., et al.: Relationship between HbA1c and Continuous Glucose Monitoring in Chinese Population: A Multicenter Study. Plos One, 8: e83827, 2013. 
50- BEHARY P., GODSLAND I. and BAYNES B.: Indices of beta-cell function: Association with diabetes control in patients with type 2 diabetes on stable GLP-1 agonist treatment. Practical Diabetes, 31: 202-5, 2014.

51- AL-HAKEIMH and ABDULZAHRA M.: Correlation between glycated hemoglobin and HOMA indices in type 2 diabetes mellitus: Prediction of Beta cell function from glycated hemoglobin. J. Med. Biochem., 34 (2): 191-9, 2014.

52- BOWER J., APPEL L., MATSUSHITA K., YOUNG H., ALONSO A., BRANCATI F., et al.: Glycated Hemoglobin and Risk of Hypertension in the Atherosclerosis Risk in Communities Study. Diabetes Care, 35: 1031-7, 2012.

53- DAHLQVIST S., AHLÉN E., FILIPSSON K., GUSTAFSSON T., HIRSCH I., TUOMILEHTO T., et al.: Variables associated with $\mathrm{HbA} 1 \mathrm{c}$ and weight reductions when adding liraglutide to multiple daily insulin injections in persons with type 2 diabetes (MDI Liraglutide trial 3). B.M.J. Open Diabetes Research \& Care, 6: e000464, 2018.

54- HAMMAD S., DARAWAD, HOURANI E. and DEMEH W.: Predictors of Glycated Hemoglobin among Jordanian Diabetic Patients. Iran J. Public Health, 44 (11): 148291, 2015.
55- HUSAIN A., ALI I., IJAZ M. and RAHIM A.: Correlation between hemoglobin A1c and serum lipid profile in Afghani patients with type 2 diabetes: Hemoglobin A $1 \mathrm{c}$ prognosticates dyslipidemia. Adv. Endocrinol. Metab., 8 (4): 51-7, 2017.

56- ANYANWU A., FASANMADE O., ODENIYI I., IWUALA S., COKER H. and OHWOVORIOLE A.: Effect of Vitamin D supplementation on glycemic control in Type 2 diabetes subjects in Lagos, Nigeria. Indian J. Endocrinol. Metab., 20 (2): 189-94, 2016.

57- SABHERWAL S., BRANS V. and DEVENDRA D.: Effect of oral Vitamin D and calcium replacement on glycaemic control in South Asian patients with Type 2 diabetes. Int. J. Clin. Pract., 64: 1084-9, 2010.

58- ABDALLAH A.Y.: Vitamin D supplementation and glycaemic control in patients with type 2 diabetes mellitus, a retrospective cohort study. Res. J. Med. Sci., 7: 44-50, 2012.

59- NIKOOYEH B., NEYESTANI T.R., FARVID M., ALAVI-MAJD H., HOUSHIARRAD A., KALAYI A., et al.: Daily consumption of Vitamin D-or Vitamin D+ calcium. Fortified yogurt drink improved glycaemic control in patients with type 2 diabetes: A randomized clinical trial. Am. J. Clin. Nutr., 93: 764-71, 2011.

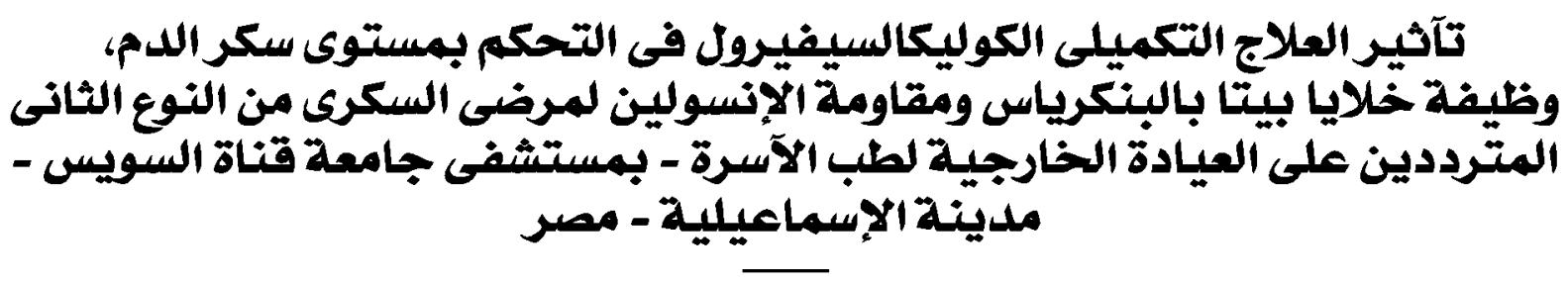

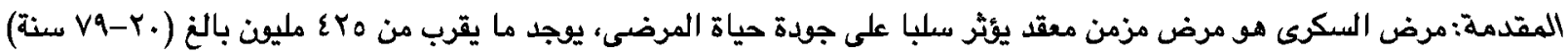

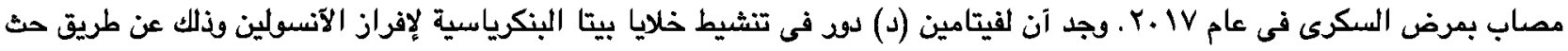

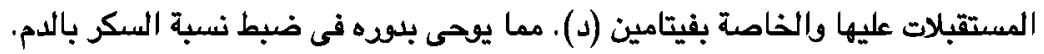

الهدف:رفع مستوى العناية المقدمة إلى مرضى السكر وذلك عن طريق الوصول لآفضل مستوى للتحكم بنسبة السكر فى الدم.

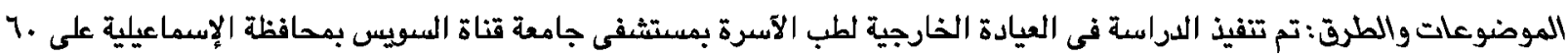

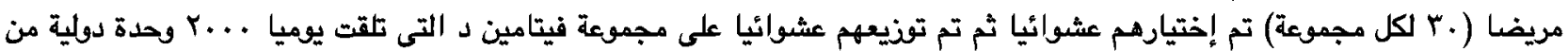

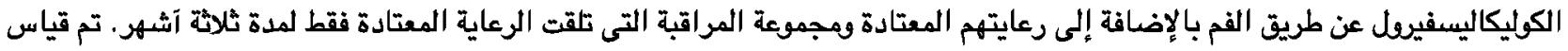

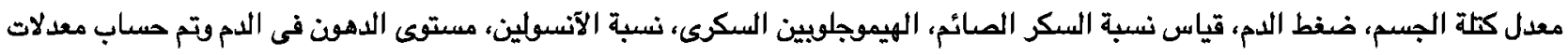

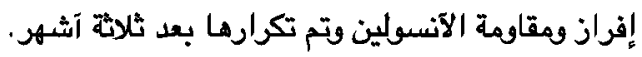

النتائج: التدخل بإستخدام فيتامين د آظهر فروق ذات دلالة إحصائية بين مجموعة التدخل ومجموعة المراقبة فى ضفط الدم والسكر الصائم

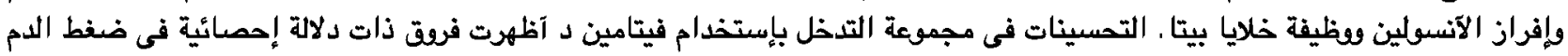

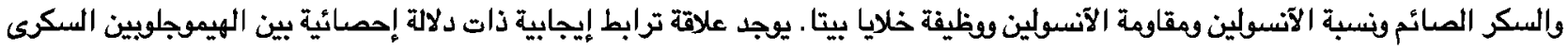
وضغط الدم والسكر الصائم. بينما يوجد علاقة ترابط سلبية ذات دلالة إحصائية بين الهيموجلوبين السكرى ونسبة الآنسولين وفظيفة خلايا

الخلاصدة: إضافة جرعة يومية ... . وحدة دولية من فيتامين د عن طريق الفم لمرضى السكرى من النوع الثانى قد يكمن مفيدا من خلال تصسين ضغط الدم، معدل السكر الصائم ووظيفة خلايا بيتا. 